\title{
Back Lanes as Social Spaces in Chinatown, Kuala Lumpur
}

\author{
Wan Hashimah Wan Ismail*, Low Hui Ching \\ Department of Architecture, Faculty of Built Environment, Universiti Teknologi Malaysia, 81310 Skudai, Johor, Malaysia
}

\begin{abstract}
The back lane is often associated with annoying, disgusting, narrow and dark. This paper concerns the use of the back lanes of the old shop houses in China Town, Kuala Lumpur. The instruments used in collecting data include observation, unstructured interview and literature review. The use and physical characteristics of back lanes were identified. It was found that the back lanes of China Town in Kuala Lumpur showed the success of turning back streets into lively alleys. Thus, the back lane could be considered as part of urban design strategies and not as leftover spaces.
\end{abstract}

(C) 2016. The Authors. Published for AMER ABRA by e-International Publishing House, Ltd., UK. This is an open access article under the CC BY-NC-ND license (http://creativecommons.org/licenses/by-nc-nd/4.0/).

Peer-review under responsibility of AMER (Association of Malaysian Environment-Behaviour Researchers), ABRA (Association of Behavioural Researchers on Asians) and CE-Bs (Centre for Environment-Behaviour Studies), Faculty of Architecture, Planning \& Surveying, Universiti Teknologi MARA, Malaysia.

Keywords: back lane; social place; pedestrian; urban

\section{Introduction}

The narrow roads in-between rows of buildings or shops are commonly known as back lane. The back lane is often associated with annoying, disgusting, narrow and dark. It is commonly considered as the back yard and often under-appreciated by the community. On the contrary, the front portions of the buildings are often adorned with ornaments and landscaping. The back lanes are also associated with crimes especially if they are dark and dirty. Petty crimes are often reported to happen in the back lanes.

However, the back lanes are mandatory, as required by the local authority in any urban design. It is compulsory to separate rows of houses or shops with back lanes. They are also a necessity and commonly used as the servicing yard. The activities at the back lanes include the collecting of rubbish and sending goods. Apart from that, they also serve as the fire breaker to prevent it from spreading to the next row of buildings. Thus, back lanes are necessary in the design of either shops or houses in the housing estates or urban areas.

The back lanes are not often considered as social spaces. This aspect was noted by Martin (2000) who emphasizes that most post-war neighborhoods in North America do not include back lanes as "social landscapes" of

${ }^{*}$ Corresponding author. Tel.:

E-mail address: wan7137shima@gmail.com

2398-4287 @ 2016. The Authors. Published for AMER ABRA by e-International Publishing House, Ltd., UK. This is an open access article under the CC BY-NC-ND license (http://creativecommons.org/licenses/by-nc-nd/4.0/).

Peer-review under responsibility of AMER (Association of Malaysian Environment-Behaviour Researchers), ABRA (Association of Behavioural Researchers on Asians) and cE-Bs (Centre for Environment-Behaviour Studies), Faculty of Architecture, Planning \& Surveying, Universiti Teknologi MARA, Malaysia.

DOI: http://dx.doi.org/10.21834/e-bpj.v1i3.373 
the society. The locals rely on the streets at the front of the houses for social interaction. However, recently the back lanes have been indicated as an opportunity to revive pedestrian activities in fostering the relationship between neighborhoods. Back lane will be a vital key to urban design to revitalize the street as a lively social space (Hess, 2008).

This paper concerns the use of the back lanes as social spaces. The research was done at China Town, Kuala Lumpur that consists of rows of old shop houses, separated by back lanes. The area is well known as shopping haven among the locals and the tourists especially along the front parts of the shophouses. China Town had its own historical value and high forces that tie the local community together. The facades, ornament, layout, typology and material have been changed from time to time, but there was still one important element of the shophouse that was left out. The ignored parts were the back lanes

Most of the people know the existence of the back lane, but they do not realize the need, the functions and its potential as a social place. The study was done to clarify the functions, physical elements and the significance of the back lane to the users in China Town, Kuala Lumpur, Malaysia. The primary aim is to enhance the public view towards the back lane and to promote better design considerations in the design of urban areas.

\section{Literature review}

Terry Slater (1988) notes that back lane is a roadway often found in a planned medieval village running parallel to the main street. The back lanes on each side of the main road, together with the main street provide a rectangular framework for the development of the settlement. According to Oxford dictionary (2015), back lane is defined as the back of a place, contrary from the front, a part furthest from the front and less visible or less important. Lane means a narrow road, usually has house on its left and right side. Some back lanes especially within the commercial district one even survive as a street name although it is a narrow pathway (Nikolaus, 1995).

Back lanes can be found in the communities of a variety of cultures from ancient Greek to Egyptian to Indonesian, long before they became commonplace in European settlements such as bastides which among other archetypes were the immediate predecessors of North American urban forms (Morris, 1993; Kostof, 1992; Sullivan, 1980). Similarly, there are also back lanes in China Town, Kuala Lumpur. As an example, the High Street, currently known as Tun Hs Lee Street, consisted of rows of shop houses with back lanes and were built in the 1880s. The shop owners were required to leave space for a path behind the shop houses. The request by the town planners was the space to be wide enough for bullock carts to move through to collect sewage and for the fire brigade whenever necessary.

Back lane can be defined, as a back route that is used as services on a building (Tawil et al., 2013). It is used for utilities and infrastructure route such as maintenance of sewerage, drainage as well as garbage collection. Back lane cannot be eliminated as it plays a significant role in urban design especially in term of safety consideration. For instance, a back lane which divides the shop houses into separate rows, to prevent the fire from spreading. In Malaysia, Back Lane Planning Guidelines 2012 outlining the back lane as emergency routes for the fire escape. Besides having deliveries or parking purposes, Slatter (1988) states that back lane can also sometimes act as part of a secondary vehicular network.

The back lanes can also be a place for neighbors to socialize, children to play and a variety of social interaction purposes (Beasley, 1996; Martin, 2000). Back lanes link the informal backyards of a particular block together, providing a form of semi-public "commons". The significance of this block-scale commons is under-appreciated because the back lanes themselves are easily overlooked by the outsider as open social space. The back lane is not typically the realm of the outsider, so the back lane may not be familiar or evident to the outsider. Back lanes provide a semi-public, intimate setting for casual social interactions, which may not be possible in more formal, public settings such as street-facing front yards (Martin, 2002). Recently, back lanes have been indicated as an opportunity to revive pedestrian activities in fostering the relationship in neighborhoods (Zelinka \& Beattie, 2003).

However, Clay (1980) mentions that back lanes tend to be a forgotten space which attracts problems and increases the crime rate. Back lanes can be a negative element of urban planning and creates an issue for the city. Back lanes have often been forgotten which no one seems to care. Frank Lloyd Wright had decreed back lane to be wasteful and unsightly anachronism row (Wright, 1916). The statement was supported by a study by Martin (2000) 
and Beasley (1997) who studied back lane networks in Oregon and Galveston, Texas. They suggest that back lane is a wasteful, unattractive and ugly space. Tawil (2013) relates the great crime rates cases occurred in the back lanes due to being narrow, dark and quiet.

In Malaysia, laws provision on back lane is stated in Road, Drainage and Building Act 1974, Uniform Building by Laws 1984 as well as Town and Country Planning Act 1976. In UBBL 1984 (140), all building more than 7000m3 shall abut upon a street or road or open space of not less than $12 \mathrm{~m}$ width and accessible to fire brigade appliances. Two or more storey exits are required. The back lane shall be spaced at not less than $5 \mathrm{~m}$ apart measured between the nearest edges of the opening. Each exit shall give direct access to a final exit, a protected staircase leading to final exit and an external route leading to a final exit (UBBL 1984, 174). The Road, Drainage and Building Act 1974 (Act 133, Part IV) also stated that back lane is part of the local authority owned. The act extends to the declaration of the back lane as a public road. No person shall erect any obstacles or additional structure in the back lane.

\section{Methodology}

Several instruments were used in the study. Primary data is collected through observation and unstructured interview. The use and physical characteristics of back lanes were identified as these elements play primary roles to the importance of back lanes. The observation was carried out daily, covering both weekdays and weekends, and from 7.30 a.m. until 10.30 p.m. for two weeks. The interview was done with local people to check the accuracy of the impressions gained through observation. The types of interviews used include a conversation using questions emerged from the immediate context and unstructured interview, comprising several topics on back lane. The interviewees ranged from youth (12-18 years old) to old folks (50 and above). They comprised of residents and tourists as well, including students, shopkeepers, eaters and tourists.

Secondary data was collected through literature review, mainly published printed sources and published electronic sources. Through literature review, the definition, history and evolution of back lane can be easily identified. The analysis of data was done by comparing different information collected previously.

\section{Findings \& Discussions}

The function and physical design of back lane features of China Town had changed over the years. The changes were due to urbanization and community needs. The back lane that is around $7 \mathrm{~m}$ wide has been utilized in different manners.

\subsection{Functions}

For more than 100 years, the functions of back lane varied according to community needs. Sultan Street and Petaling Street were famous of food trail. Some back lanes of these streets (Figure 1a) were occupied by food stalls and slowly evolved into food streets. Gallery Penjaja at Tun HS Lee Street which was situated between Guan Di Temple and shop houses along Sultan Street has been converted into a wet market (Figure 1b). One of the significant back lanes known as Lorong Tikus or Mice Lane was a famous place for selling second-hand goods. The local community organized the use of space. However, the commercial activities stopped at noon, and the back lanes became ordinary back lanes which act as the backyard of the shop houses. Then back lanes served as informal communal spaces for neighbors to interact and access points for infrastructure services. 


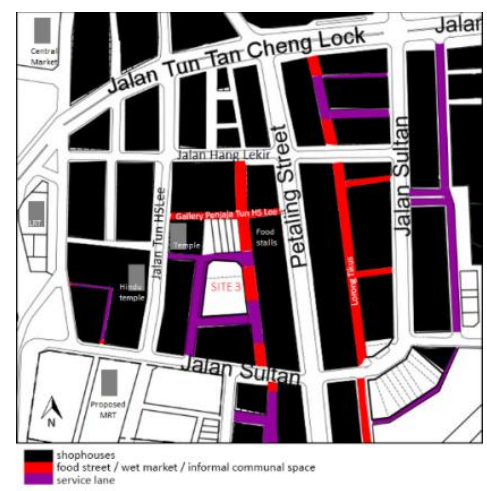

(a)

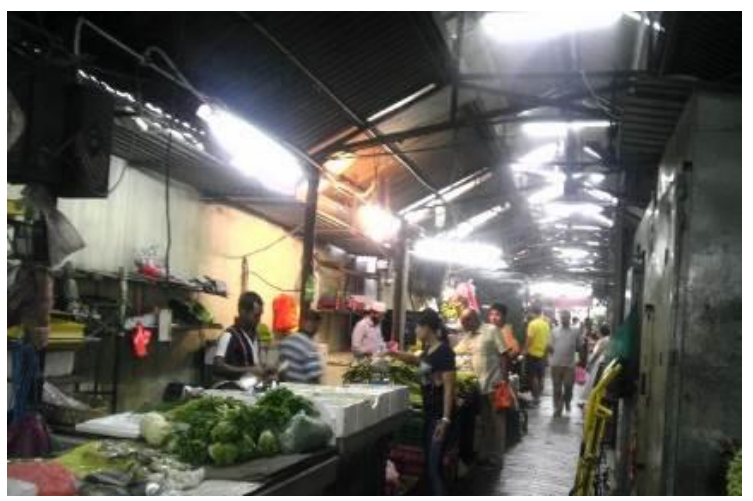

(b)

Fig.1 (a) The location of back lanes at China Town, Kuala Lumpur: (b) Wet market at Penjaja Gallery Tun Hs Lee.

\subsection{Physical elements}

There were some physical characters of the back lanes that influenced different activities. The negative aspects of the back lanes in China Town were improved by the local community to suit their activities. The human scale of the alley between two shop houses creates an urban composition that is unique and readily recognizable thus assisting in creating a clear sense of place. Space relates to the human scale and able to provide a very comfortable interactive distance between vendors and pedestrians. A comparison can be done between the modern supermarket and traditional wet market. The later one has more individualized service and ability to cater each customer's needs. For example, a spice vendor did not just selling spices but also shared his personal cooking experiences. The customers and the vendors passed on knowledge through face-to-face interactions. This was best demonstrated by the wet market at Penjaja Gallery Tun Hs Lee, at the back lane perpendicular to Petaling Street.

There were several entrances for the users to get to the wet market of China Town and it was situated in the back lane. According to Greig and Stephenson (2012), a thriving market is one that has a strategic location, easy accessibility, and precise interior layout. The back lane wet market was situated at the town center where it is close to several important gathering nodes such as Guan Di Temple and Petaling Street. The linear wet market alley also allows the users to orientate themselves and find what they need so that they will not be lost in the wet market. These are the key points that the wet market in Penjaja Gallery Tun Hs Lee can be so lucky regarding accessibility. This aspect is similar to the food stalls at the back lane that has well prepared outdoor seating, seems like inviting the passer-by to sit down and enjoy the food. The food stalls are also easily assessed by everyone.

The wet market in Chinatown was covered by jack roof, to improve the ventilation. Ventilation played a crucial role in wet market design for the comfort of the users. The users could interact in comfort due to proper ventilation in the wet market. Apart from ventilation, the jack roof is responsive to the hot, humid climate and the drenching rain as well. There was also temporary shelter in canvas that shaded the food street from rain and sun. However, the shelter food street is less perfect compared to jack roof which was a permanent shelter. Apart from the built structures, there were also trees at the back lane that contributed in the shading of the back lane. This aspect added to the informal communal space for the community to gather in fostering the neighborhood relationship.

Tibbalds (2001) notes that he presence of people on the street from the simple Chinese shoemaker in Beijing to tourists in Amsterdam makes lively, exciting, public environment. This situation is quite similar to the back lane of Sultan Street where the activities offer a high degree of transparency for pedestrians, which made the back lane be an active node. The wet market plays a role in attracting the people to come and bond in space.

There was a practice of transparency in the selling of goods along Mice Lane (Figure 2a), the back lane of Petaling Street. The traders displayed their goods on the floor or wall to be fully seen by the passers-by. The customers could easily see and choose what they wanted easily. This situation encourages more customers to stop and look as well as buy goods from the stalls. The display of the merchandise increases the degree of transparency, as one can witness the activities (Shuhana, 2011). Similarly, food stalls in the area also practiced transparency. 
Some of the food were prepared, displayed and served next to the sitting spaces at the back lane. The aroma of the food, the sound they produced and the sense of colors filled the spaces and enriched the sensory effect of the townscape.

\subsection{Urban contribution}

As mentioned by Jacobs (1961), most blocks must be short; that is, streets and opportunities to turn corners must be frequent. This aspect could be clearly seen at China Town. There were gaps in between the rows of the shop houses which create more places for commerce and for encountering people. The side lanes in between two rows of shop houses created a gap which contributed to the social and economic life of China Town. It can be imagined that, if the shop houses are a long row without the break, people is forced in a prescribed direction that may not be the most desirable path to a destination. At the same time, the pedestrians have to follow a monotonous, alwaysthe-same path to a given point, where they will have fewer opportunities to meet different people or shop at various stores. The back lane offers an opportunity for pedestrians to turn and follow an alternate path. In fact, some side lanes act as a shortcut route to certain point. Some of these gaps were used as entrances to the back lane, as selling and eating areas. Pedestrians could more easily interact with one another and a range of businesses gave the area its diversity.

The over-crowded and heavy traffic of the main streets (Figure $2 b$ ) decreased the comfort of the pedestrians. Some of the users preferred the more peaceful back lane. The back lanes which were converted into a wet market, eateries, commercial area as well as informal communal spaces had enhanced the social and economic life of the area.

The back lanes need to be managed properly to prevent problems (Clay, 1980) and increase the crime rate (Tawil, 2013). The presence of people due to the exciting activities happening at the back lanes of Sultan Street made the back lane safer. The backs of the shop houses were not left empty to ensure the safety of both shopkeepers and visitors. The back lanes also became pedestrian prior and prompt with people, which created a fairly continuous human flow, increases the number of effective eyes on the street (Jacobs, 1961). This aspect could be clearly seen in a car park surrounded by back lanes that tend to become a negative area. However, the activities at the back lanes of China Town had prevented it from turning into a criminal spot. The reason is the number of effective eyes of onlookers from the wet market, the food stalls as well as informal communal spaces behind the shop houses.
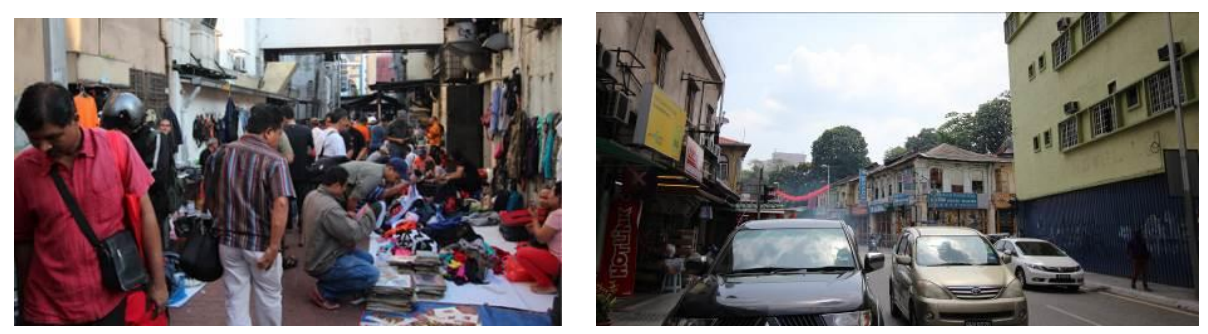

Fig. 2.(a) The selling of second hand goods at Mice Lane; (b) Heavy traffic at Sultan Street.

A variety of activities and experiences made a place to become attractive. Urban areas will be killed by zone separation of uses (Francis, 2001). Jane Jacobs (1961) also suggested that the most economically successful areas, as well as those most pleasant to be in, have mixed uses, not just all one kind of thing. Besides, the related activities of the street also contribute to the urban quality of particular space, apart from the physical form of shop houses. The combination of varied activities happens in the back lane established a lively and vibrant urban setting that typified a living city. The Mice Lane provided space for the community to resell second-hand stuff, while food stalls occupied the end of Mice Street. Besides, Penjaja Gallery Tun HS Lee held a variety of functions such as wet market and food street. The mixed uses of the back lane had successfully created a more livable town.

However, the old shop houses are under threats of extinction. The loss of attention on the values of a heritage building, lack of control of the local government, lack of funds and so on are the problems that cause the old shop houses destructed (Wan Hashimah, 2012). When destruction happens, the shop houses, especially rear facade or back lane which tend to be forgotten by the users, will be the first and most significant changed ones. The 
destruction will somehow affect the back lane activities. When this happens, the back lane will become a quiet, dark and less used by the community which may bring a lot of problems to the society later. Therefore, it is recommended that appropriate measures should be carried out to raise the awareness of people in preserving the unique characteristics of back lane. However, the Government should be the one that takes the initiatives to preserve and revitalize back lane.

\section{Conclusion}

Back lanes tend to become backyard, service routes and fire escape routes for shop houses. However at China Town, the back lanes have been utilized for other functions which turn the back lanes into social interaction spaces. We can conclude that the back lane which was an unpleasant and harmful element for urban scape, nowadays, has changed into a vibrant and lively node.

It cannot be denied that back lane does play a significant role in contributing lively neighborhood. The evolution of back lane from service lane into other interesting functions has successful activate the back lane to avoid negative spaces and to increase crime rate in the city.

This situation can be seen from Penjaja Gallery Tun HS Lee Street which is a wet market and food street at the back lanes. The back lane is being further improved to suit the particular usage. The most concrete example is the jack roof that constructed to meet the requirement of the wet market in improving ventilation. The street selling food also becomes an informal communal place for people to gather and interact. All the activities that happen naturally at back lanes shall thank its unique characteristics. For instance, the human scale, degree of transparency of goods and activities, easily accessed by people and other more physical elements of back lane have successfully turned back lanes into entertaining space.

It cannot be denied that the evolution of back lane has slowly contributed to urban scape in a positive manner. The back lane offers an opportunity for pedestrians to turn and follow an alternate path. Interactions among the pedestrians could be more easily happened and a range of business, give the area its diversity. The back lane also tends to be more comfortable for people to socialize as the frontage of shop houses are exposed to heavy traffic flow. Jane Jacob (1961) mentioned about "eyes on streets," which the vibrant activity happens at the back lane has increased the number of effective eyes on the street and thus lower the rate of crime. The mixed uses of the back lane, for instance at Mice Lane comprises of second-hand goods selling and eating, contributed to the lively and vibrant urban setting that typified a living city.

The back lanes of China Town in Kuala Lumpur, are best demonstrated the success of turning back streets into attractive and lively alleys. Most of the people know the existence of the back lane, but they do not realize the needs and the functions of back lane beyond serving for services. Even though the back lanes are popular, some effort is required to improve the condition of the area. The improvement can include the painting of the walls and paving the streets. The primary intention is to ensure that the back lanes of China Town remain popular and used appropriately in the future. The back lanes can also become exemplary in the design of social spaces in urban areas.

\section{Acknowledgements}

This study was made possible by the continuous support from Universiti Teknologi Malaysia.

\section{References}

Beasley, E. (1997). The alleys and back buildings of Galveston-Architectural and Social History. Houston: Rice University Press.

Clay, G. (1980). Close-up: How to read the American City (2nd ed.). United States of America: Chicago Press. 
Hess, P. M. (2008). Fronts and backs: the use of streets, yards, and alleys in toronto-area new urbanist neighborhoods. Journal of Planning Education and Research, (28), 196-201

Jacobs, J. (1960). The death and life of great American cities. New York: Modern Library.

Kostof, S. (1992). The city assembled. London: Thames and Hudson Ltd.

M. Tawil, N., F. Md Lias, S., M. S. Usman, I., I. M. Yusoff, N., I. Che Ani, A. and A. Kosman, K. (2013). Evolution of back lane design: a view of terrace housing in Malaysia. ASS, 9(15).

Martin, M. (2000). Endangered landscapes: residential alley transformations. APT Bulletin, 31(4), 39- 45.

Martin, M. (2002). The case for residential back alleys: a North American perspective. Journal of Housing and the Built Environment, 17(2), 145171.

Morris, A.E.J. (1993). The history of urban form before the industrial revolutions. New York: John Wiley \& Sons.

Nikolaus (1995) [1972]. Yorkshire: York and the East Riding (2nd ed.). London: Penguin Books.

Shuhana Shamsuddin (2011).Townscape Revisited: Unraveling the character of the historic townscape in Malaysia. Johor: Penerbit UTM Press.

Slater (1988). 'English medieval town planning,' in Denecke D \& Shaw G (Eds.), Urban historical geography: recent progress in Britain and Germany. Cambridge Studies in Historical Geography, 10. Cambridge: Cambridge University Press, 93-108.

Sullivan, J. (1980). Back alley neighborhood: Kampung as urban community in Yogyakarta. Melbourne: Centre for Southeast Asian Studies.

Tibbalds, F. (2001). Making people-friendly towns: improving the public environment in towns and cities. New York: Spon Press.

Wan Hashimah (2012). Users and the survival of the shop houses in the Historic City of Malacca. Science Direct Elsevier PROCEDIA -Social and Behavioral Sciences. Volume 42. 443-450

Zelinka, A., \& Beattie, W. (2003). How to turn alleys into allies. Planning Magazine, 69(10), 25. 